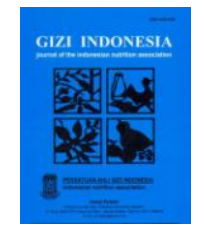

\title{
SURVIVAL RATE PENYANDANG HIPERTENSI DENGAN KONSUMSI NATRIUM RENDAH TERHADAP KEJADIAN STROKE
}

\section{Survival Rate of Hypertension with Low Sodium Intake on the Incidence of Stroke}

\author{
Ekowati Rahajeng, Woro Riyadina \\ Pusat Penelitian dan Pengembangan Upaya Kesehatan Masyarakat, Badan Penelitian dan \\ Pengembangan Kesehatan, Kementerian Kesehatan RI. Jl. Percetakan Negara 29 Jakarta, Indonesia \\ E-mail: ekowatir@litbang.depkes.go.id; ekowatir@gmail.com
}

\begin{abstract}
Stroke is the leading cause of death and disability in the world. Several studies have shown that stroke can be prevented through modifiable risk factors. The adequate treatment of hypertension may reduce the risk of stroke. Lifestyle modification such as reducing salt intake in hypertension management have demonstrated lowering blood pressure, enhancing the effectiveness of antihypertension drugs and also reducing stroke risk. This study aims to verify the survival rate of hypertension with lower sodium intake ( $<2000 \mathrm{mg}$ per day) on the incidence of stroke. The study was conducted through a prospective cohort study (4 years of follow-up) in 1082 people with confirmed hypertension. Stroke were confirmed by neurologist. The consumption of sodium, sugar and fat were collected through 24-hour dietary recall. Hypertension survival rate was calculated using Life Table Survival analysis. This study has demonstrated evidence of the higher survival rate of hypertension with low sodium intake on the incidence of stroke, with the difference 2-year survival rate is 3 percent higher and 4-year survival rate is 5 percent higher. Sodium consumption of $<2000 \mathrm{mg}$ per day in people with hypertension has prevented a 78 percent incidence of stroke. Therefore, the intervention programs to reduce of the consumption of salt or sodium in Indonesia should be prioritized.
\end{abstract}

Keywords: stroke, survival rate, sodium intake, cohort study

\section{ABSTRAK}

Stroke merupakan penyebab utama kematian dan kecacatan di dunia. Beberapa penelitian telah menunjukkan bahwa kejadian stroke dapat dicegah melalui faktor risiko yang dapat dimodifikasi. Pengobatan hipertensi secara adekuat dapat mengurangi risiko stroke. Modifikasi perilaku seperti mengurangi konsumsi garam pada penatalaksanaan hipertensi dapat mengendalikan tekanan darah, dan meningkatkan efektivitas obat antihipertensi dan juga mencegah risiko stroke. Studi ini bertujuan untuk membuktikan survival rate (waktu ketahanan) penyandang hipertensi yang mengonsumsi natrium rendah ( $<2000 \mathrm{mg}$ per hari) terhadap kejadian Stroke. Penelitian dilakukan melalui studi kohor prospektif (4 tahun pengamatan), pada 1082 penyandang hipertensi, yang terdiri dari 73 orang mengonsumsi natrium tinggi dan 1009 orang mengonsumsi natrium rendah. Kejadian stroke ditetapkan berdasarkan adanya gangguan neurologis atau gejala klinis tersebut yang dikonfirmasi dengan pemeriksaan klnis oleh dokter spesialis saraf. Konsumsi natrium, konsumsi gula dan lemak dikumpulkan melalui recall makanan satu kali 24 jam dan wawancara menggunakan Food Frequency Questionaire. Survival rate hipertensi dihitung dengan Life Table Survival analysis. Studi ini telah berhasil menunjukkan bukti lebih tingginya waktu ketahanan terhadap kejadian stroke, bagi penyandang hipertensi yang mengonsumsi natrium rendah dibandingkan yang mengonsumsi natrium tinggi, dengan perbedaan 2 tahun-survival rate 3 persen lebih tinggi dan 4 tahun-survival rate 5 persen tinggi. Konsumsi natrium $<2000 \mathrm{mg}$ per hari pada penyandang hipertensi telah mencegah sebesar 78 persen kejadian stroke. Karena itu, program intervensi untuk mereduksi konsumsi garam atau natrium di Indonesia perlu segera diprioritaskan.

Kata kunci: stroke, survival rate, konsumsi natrium, studi kohor 


\section{PENDAHULUAN}

S troke merupakan penyebab kematian nomor 3 di dunia setelah penyakit jantung dan kanker, baik di negara maju maupun berkembang. Di Amerika pada 2011 ditemukan insiden stroke 795.000 orang, prevalensi 2.980 .000 orang dan mortalitas akibat stroke 150.000 orang pertahun..$^{1-3} \mathrm{Di}$ Indonesia stroke, merupakan penyebab kematian tertinggi pada semua kelompok umur dengan proporsi 15,4 persen. Pada kelompok umur 55-64 tahun kematian akibat stroke mencapai 26,8 persen.., 5 Penelitian epidemiologi stroke regional Asia Timur selama tahun 1984-2004 menemukan angka insiden di Cina sebesar 483 per 100.000 penduduk, di Jepang 201 per 100.000 penduduk. ${ }^{6}$ Insiden stroke di Singapura pada tahun 2007 adalah 174,5 per 100.000 penduduk, dan pada tahun 2013 menjadi 158,3 per 100.000 penduduk. ${ }^{7}$ Thai Epidemiologic Stroke Study (TES) pada tahun 2004-2006 mendapatkan prevalensi stroke di Thailand sebesar 1,88 persen $(95 \% \mathrm{Cl}, 1,69$ $2,07) \cdot{ }^{8}$ Sementara di Indonesia, hasil Riskesdas menunjukkan prevalensi stroke pada tahun 2007 adalah 8,3 per 1000 penduduk, meningkat menjadi 12,1 per 1000 penduduk pada tahun 2013.4,5

Stroke merupakan penyebab kecacatan tertinggi di masyarakat. Separuh dari mereka yang mengalami stroke akan mengalami kecacatan fisik. Beban utama akibat stroke adalah kecacatan yang menimbulkan beban psikologis, dan biaya tinggi baik bagi penderita, maupun keluarganya. Stroke juga telah meningkatkan beban ekonomi negara. Beban tersebut tidak hanya akibat penyakitnya yang membutuhkan pelayanan kesehatan dan pengobatan. Namun juga diakibatkan menurunnya dan hilangnya produktivitas penderita stroke, dan keluarganya. Penelitian di Amerika Serikat menunjukkan biaya sebesar 65,5 miliar dolar telah dihabiskan dalam waktu 1 tahun untuk perawatan dan biaya kompensasi karena penurunan produktivitas yang berhubungan dengan kejadian stroke dan kecacatan yang diakibatkannya. ${ }^{1-3}$

Tingginya peningkatan tekanan darah erat hubungannya dengan risiko terjadinya stroke. Hipertensi merupakan faktor risiko utama terjadinya perdarahan intraserebral dan subaraknoid yang merupakan jenis perdarahan utama pada stroke. Hipertensi memegang peranan penting pada patogenesis aterosklerosis pembuluh darah besar yang selanjutnya akan menyebabkan stroke iskemik oleh karena oklusi trombotik arteri, emboli arteri ke arteri atau kombinasi keduanya. Stroke kardioembolik juga lebih sering terjadi pada individu dengan hipertensi dan penyakit jantung. Hipertensi merupakan faktor risiko utama stroke yang dapat dimodifikasi. ${ }^{9,10}$

Selain tekanan darah tinggi, peningkatan kadar kolesterol adalah faktor risiko penting terjadinya aterosklerosis. Faktor risiko lainnya adalah merokok, stres, kurang aktivitas fisik, konsumsi gula, lemak dan natrium berlebihan dapat memicu terjadinya aterosklerosis pada dinding pembuluh darah, yang pada akhirnya menyebabkan stroke. Beberapa studi mendapatkan bahwa, pengurangan konsumsi natrium pada orang dewasa secara bermakna mengurangi tekanan darah sistol sebesar 3,39 $\mathrm{mm} \mathrm{Hg}(95 \% \mathrm{Cl} 2,46-4,31)$ dan tekanan darah diastol sebesar $1,54 \mathrm{~mm} \mathrm{Hg}(95 \% \mathrm{Cl} 0,98-$ 2,11 ). Sementara konsumsi natrium $<2000 \mathrm{mg}$ per hari telah menurunkan tekanan darah sistol sebesar $3,47 \mathrm{~mm} \mathrm{Hg}(95 \% \mathrm{Cl} 0,76-6,18)$ dan tekanan darah diastol sebesar $1,81 \mathrm{~mm} \mathrm{Hg}$ $(95 \% \mathrm{Cl} 0,54-3,08) \cdot{ }^{9-12}$

Kejadian stroke dapat dicegah melalui faktor risiko yang dapat dimodifikasi. Selain melalui pengobatan hipertensi secara adekuat, pola hidup sehat banyak disarankan dalam penatalaksanaan hipertensi. Tidak merokok, memperbanyak akitivitas fisik, diet yang sehat seperti mengurangi konsumsi gula, garam, dan lemak, serta memperbanyak konsumsi sayur dan buah, merupakan kombinasi perilaku hidup sehat yang efektif dalam mengendalikan meningkatnya tekanan darah. ${ }^{13-16} \mathrm{Di}$ Indonesia proporsi penduduk yang biasa mengonsumsi makanan asin $\geq 1$ kali sehari pada tahun 2013 adalah 26,2 persen dan penduduk yang mengonsumsi natrium tinggi ( $\geq 2000 \mathrm{mg}$ per hari) ditemukan cukup tinggi yaitu 52,7 persen, sementara program pengendalian konsumsi natrium belum menjadi prioritas. ${ }^{17}$ Studi ini bermaksud membuktikan survival rate (waktu ketahanan) penyandang hipertensi yang mengonsumsi natrium rendah $(<2000 \mathrm{mg}$ per hari) terhadap kejadian stroke di Indonesia. Sebagai dasar bukti pentingnya program intervensi pengurangan konsumsi natrium dalam pencegahan stroke di Indonesia. 


\section{METODE PENELITIAN}

Studi dilakukan melalui desain studi kohor prospektif, yang merupakan bagian dari Studi Kohor Penyakit Tidak Menular yang dilakukan di Kecamatan Bogor Tengah, Kota Bogor Provinsi Jawa Barat, Indonesia. Studi ini merupakan dinamik kohor yang dilaksanakan sejak tahun 2011, dengan jumlah populasi studi 5000 orang dewasa berusia 25 tahun ke atas. ${ }^{18}$ Analisis dilakukan pada penyandang hipertensi yang ditemukan pada survei data dasar (1414 orang), dan mempunyai kelengkapan data yang diteliti berjumlah 1082 orang, terdiri dari 73 orang mengonsumsi natrium tinggi dan 1009 orang mengonsumsi natrium rendah.

Hipertensi adalah kondisi tekanan darah yang tinggi yaitu dengan tekanan darah sistol $\geq$ $140 \mathrm{mmHg}$ atau tekanan darah diastol $\geq 90$ $\mathrm{mmHg}$, baik yang bersangkutan sedang minum obat antihipertensi ataupun tidak. Pengukuran tekanan darah dilakukan dengan menggunakan tensimeter digital. Pada saat pengukuran tekanan darah, setiap responden minimal diukur dua kali. Jika hasil pengukuran kesatu dan kedua berbeda $\geq 10 \mathrm{mmHg}$, maka akan dilakukan pengukuran ketiga. Rerata tekanan darah dari hasil pengukuran sebelumnya dengan selisih terkecil dengan pengukuran terakhir dihitung sebagai tekanan darah responden. Pemantauan tekanan darah dilakukan dengan interval waktu pengukuran 24 bulan sekali. Dalam 2 tahun pengamatan dilakukan 6 kali pengukuran tekanan darah. Responden ditetapkan memiliki kondisi tekanan darah yang tetap tinggi, apabila nilai rata-rata dari 6 kali pengukuran tekanan darah mempunyai tekanan darah sistol $\geq 140 \mathrm{mmHg}$ atau tekanan darah diastol $\geq 90 \mathrm{mmHg} .{ }^{19}$

Kejadian stroke ditetapkan sesuai kriteria WHO, yaitu stroke yang secara klinis didefinisikan sebagai gangguan fungsi otak yang terjadi secara mendadak dengan tanda atau gejala klinis baik fokal maupun global yang berlangsung lebih dari 24 jam atau dapat menimbulkan kematian yang disebabkan oleh karena gangguan peredaran darah otak. Stroke ditetapkan berdasarkan adanya gangguan neurologis atau gejala klinis tersebut yang dikonfirmasi dengan pemeriksaan klinis oleh dokter spesialis saraf. ${ }^{20,21}$
Konsumsi natrium, konsumsi gula dan lemak dikumpulkan melalui recall makanan satu kali 24 jam dan wawancara menggunakan Food Frequency Questionaire (FFQ). Faktor risiko tersebut dipantau setiap tahun (4 kali pengukuran dalam 4-tahun pengamatan). Jumlah natrium, gula dan lemak ditetapkan dengan merujuk pada Tabel Komposisi Pangan Indonesia (TKPI) tahun 2009, dan Daftar Komposisi Bahan Makanan (DKBM) tahun 2015. Batasan konsumsi natrium rendah adalah $<2000 \mathrm{mg}$ per hari. Seseorang ditetapkan telah mengonsumsi natrium rendah, apabila orang tersebut sejak awal pengamatan dan minimal 3 kali pengukuran berikutnya, biasa mengonsumsi natrium rendah.

Faktor sosiodemografi, konsumsi sayur dan buah, merokok, dan aktifitas fisik dikumpulkan melalui wawancara dengan kuesioner yang mengadopsi The WHO STEPS Instrument for Non-Communicable Diseases Surveillance. Ada tidaknya stres diukur dengan SRQ (SelfReporting Questionnaire). Faktor risiko perilaku tersebut juga dipantau setiap tahun. Seseorang ditetapkan mempunyai faktor risiko tersebut apabila dalam 4 kali pengukuran selama 4tahun pengamatan, mempunyai perilaku yang berisiko minimal 3 kali. Sementara kualitas perokok ditetapkan berdasarkan wawancara terakhir dan dihitung dengan Indeks Binkman.

Penyakit Jantung Koroner (PJK) ditetapkan berdasarkan adanya gejala klinis serangan jantung dan/atau hasil pemeriksaan EKG tidak menunjukkan kelainan jantung iskemik/infark. Diabetes Melitus ditetapkan berdasarkan adanya gejala klinis diabetes, pernah didiagnosis diabetes oleh dokter, menggunakan obat antidiabetes, dan/atau hasil pemeriksaan kadar glukosa darah puasa adalah $\geq 126 \mathrm{mg} / \mathrm{dL}$ atau hasil pemeriksaan kadar glukosa darah 2 jam sesudah pembebanan $75 \mathrm{~g}$ glukosa adalah $\geq 200 \mathrm{mg} / \mathrm{dL}$. Hiperglikemi ditetapkan berdasarkan hasil pemeriksaan kadar glukosa darah 2 jam sesudah pembebanan $75 \mathrm{~g}$ glukosa yaitu $\geq 200 \mathrm{mg} / \mathrm{dL}$. Kolesterol (total, LDL dan $\mathrm{HDL}$ ) dan trigleserida diukur melalui pemeriksaan biokimia darah.

Data yang dianalisis adalah kondisi faktor risiko dan kejadian (event) stroke yang muncul selama 4-tahun pengamatan (tahun 2011 hingga tahun 2015) melalui 2 kali pemeriksaan. Sensor adalah kondisi responden yang tidak 
atau belum mengalami stroke pada waktu kejadian ditetapkan. Survival rate stroke (waktu ketahanan terhadap stroke) dihitung dengan Life Table Survival analysis. Uji statistik Wilcoxon (Gehan) dilakukan untuk mengetahui perbedaan waktu ketahanan responden menurut faktor risiko yang diteliti.

Sebelum dilakukan Life Table Survival analysis, dilakukan pemodelan Cox Proportional Hazards Regression Multivariate Analysis untuk mengetahui faktor risiko yang berkontribusi terhadap kejadian stroke.

Pelaksanaan penelitian ini setiap tahunnya telah mendapat persetujuan etik dari Komisi Etik Penelitian Kesehatan Badan Litbang Kesehatan Kementerian Kesehatan RI.

\section{HASIL}

Selama 4 tahun pengamatan ditemukan 38 kejadian stroke pada penyandang hipertensi. Analisis multivariat dengan Regresi Cox Proportional Hazards terhadap konsumsi natrium, konsumsi lemak, konsumsi gula, konsumsi sayur-buah, merokok, aktivitas fisik, stres, hiperglikemi, hiperkolesterol (total, LDL dan HDL), hipertrigliserida, tekanan darah, PJK, minum obat antihipertensi, umur, jenis kelamin, ekonomi, perkawinan dan pendidikan, mendapatkan model analisis statistik yang paling fit (-2 Log Likelihood = 509,55).

Seperti terlihat pada Tabel 1, faktor risiko yang bermakna untuk masuk pada model tersebut adalah konsumsi natrium, hiperglikemi, hiperkolesterol, tekanan darah, umur dan jenis kelamin.

Tabel 1

Pengaruh Konsumsi Natrium Rendah pada Hipertensi terhadap Kejadian Stroke (Fit Model Cox Proportional Hazards)

\begin{tabular}{lccc}
\hline \multicolumn{1}{c}{ Faktor Risiko } & $\beta$ & $\begin{array}{c}\text { Hazard } \\
\text { Ratio }\end{array}$ & $95 \% \mathrm{Cl}$ \\
\hline Konsumsi Natrium Rendah (<2000 gram per hari) & $-1,26$ & 0,28 & $0,13-0,58$ \\
Hiperglikemi $(\geq 200 \mathrm{mg} / \mathrm{dL})$ & 0,66 & 1,934 & $1,09-3,78$ \\
Hiperkolesterol $(\geq 250 \mathrm{mg} / \mathrm{dL})$ & 1,39 & 4,042 & $2,05-7,96$ \\
Tekanan Darah Tetap Tinggi & 1,19 & 3,307 & $1,59-6,88$ \\
Umur $(\geq 40-49$ Tahun) & 1,629 & 5,098 & $0,69-17,32$ \\
Jenis Kelamin (Laki-laki) & 0,946 & 2,576 & $1,32-5,01$ \\
\hline
\end{tabular}

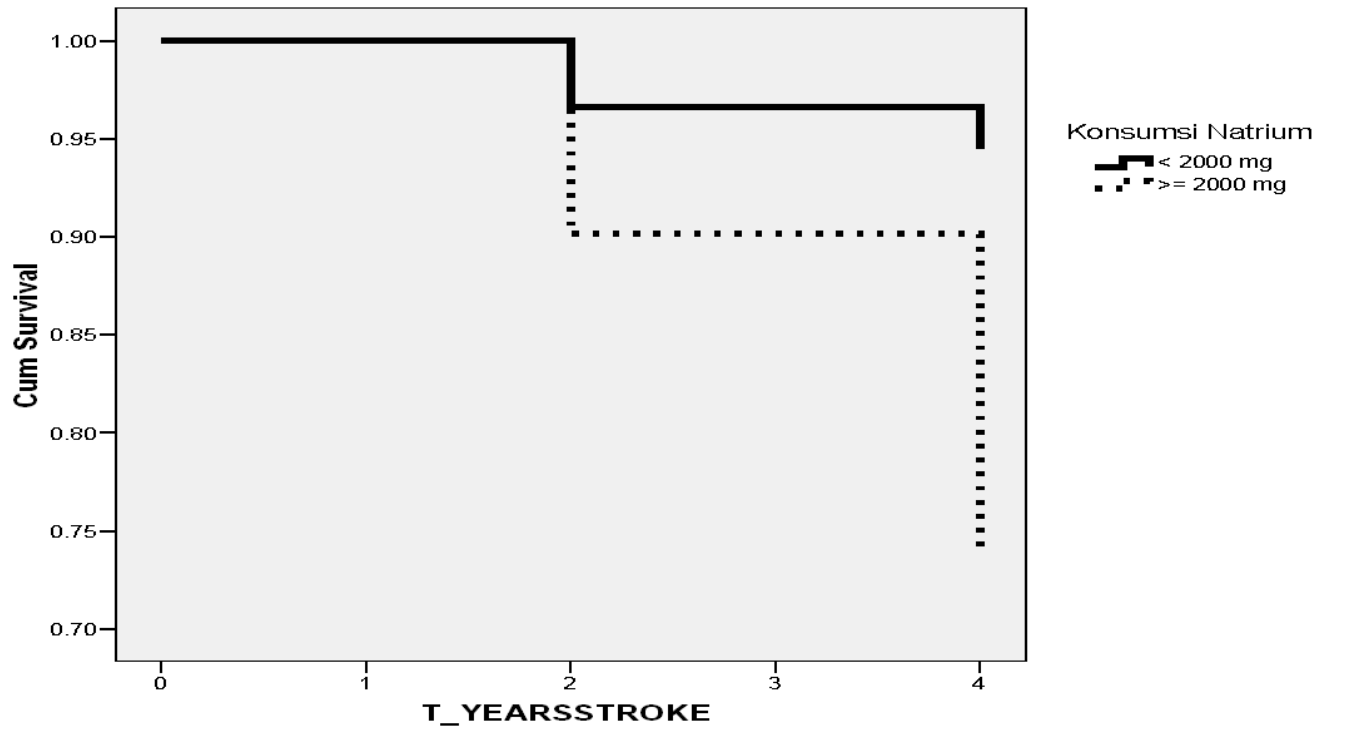

Gambar 1

Fungsi Survival Hipertensi terhadap Stroke menurut Konsumsi Natrium 
Tabel 2

Survival Rate Hipertensi terhadap Stroke menurut Konsumsi Natrium dan Faktor

\begin{tabular}{|c|c|c|c|c|c|}
\hline \multirow{2}{*}{ Faktor Risiko } & \multicolumn{2}{|c|}{$\begin{array}{l}\text { Konsumsi Natrium Rendah } \\
\quad(<2000 \text { g per hari })\end{array}$} & \multicolumn{2}{|c|}{$\begin{array}{l}\text { Konsumsi Natrium Tinggi } \\
(>=2000 \mathrm{~g} \text { per hari) }\end{array}$} & \multirow{2}{*}{$\begin{array}{c}\text { Wilcoxon } \\
\text { (Gehan) } \\
p\end{array}$} \\
\hline & $\begin{array}{c}\text { 2-tahun } \\
\text { Survival Rate }\end{array}$ & $\begin{array}{c}\text { 4-tahun } \\
\text { Survival Rate }\end{array}$ & $\begin{array}{c}\text { 2-tahun } \\
\text { Survival Rate }\end{array}$ & $\begin{array}{c}\text { 4-tahun } \\
\text { Survival Rate }\end{array}$ & \\
\hline \multicolumn{6}{|l|}{ Glukosa Darah } \\
\hline$<200 \mathrm{mg} / \mathrm{dL}$ & $97 \%$ & $96 \%$ & $95 \%$ & $79 \%$ & 0,00 \\
\hline Hiperglikemi ( $\geq 200$ mg/dL) & $94 \%$ & $86 \%$ & $67 \%$ & $52 \%$ & 0,00 \\
\hline \multicolumn{6}{|l|}{ Kolesterol Darah } \\
\hline$<250 \mathrm{mg} / \mathrm{dL}$ & $98 \%$ & $96 \%$ & $95 \%$ & $85 \%$ & 0,00 \\
\hline Hiperkolesterol ( $\geq 250 \mathrm{mg} / \mathrm{dL}$ ) & $91 \%$ & $85 \%$ & $65 \%$ & $26 \%$ & 0,00 \\
\hline \multicolumn{6}{|l|}{ Tekanan Darah Tetap Tinggi } \\
\hline Tidak & $98 \%$ & $95 \%$ & $94 \%$ & $87 \%$ & 0,00 \\
\hline $\mathrm{Ya}(\geq 140 / 90 \mathrm{~mm} \mathrm{Hg})$ & $92 \%$ & $91 \%$ & $88 \%$ & $66 \%$ & 0,00 \\
\hline \multicolumn{6}{|l|}{ Kelompok Umur } \\
\hline 25 - 39 tahun & $99 \%$ & $99 \%$ & $100 \%$ & $100 \%$ & 0,75 \\
\hline $40+$ & $96 \%$ & $94 \%$ & $88 \%$ & $68 \%$ & 0,00 \\
\hline \multicolumn{6}{|l|}{ Jenis Kelamin } \\
\hline Laki-laki & $95 \%$ & $89 \%$ & $78 \%$ & $59 \%$ & 0,00 \\
\hline Perempuan & $97 \%$ & $96 \%$ & $94 \%$ & $80 \%$ & 0,00 \\
\hline Konsumsi Natrium & $97 \%$ & $94 \%$ & $90 \%$ & $74 \%$ & 0,00 \\
\hline Konsumsi Natrium* & $98,9 \%$ & $97,9 \%$ & $95,9 \%$ & $92,9 \%$ & 0,00 \\
\hline
\end{tabular}

${ }^{*}$ Ajusted Survival Rate menurut faktor hiperglikemi, hiperkolesterol, kekanan darah, umur dan jenis kelamin

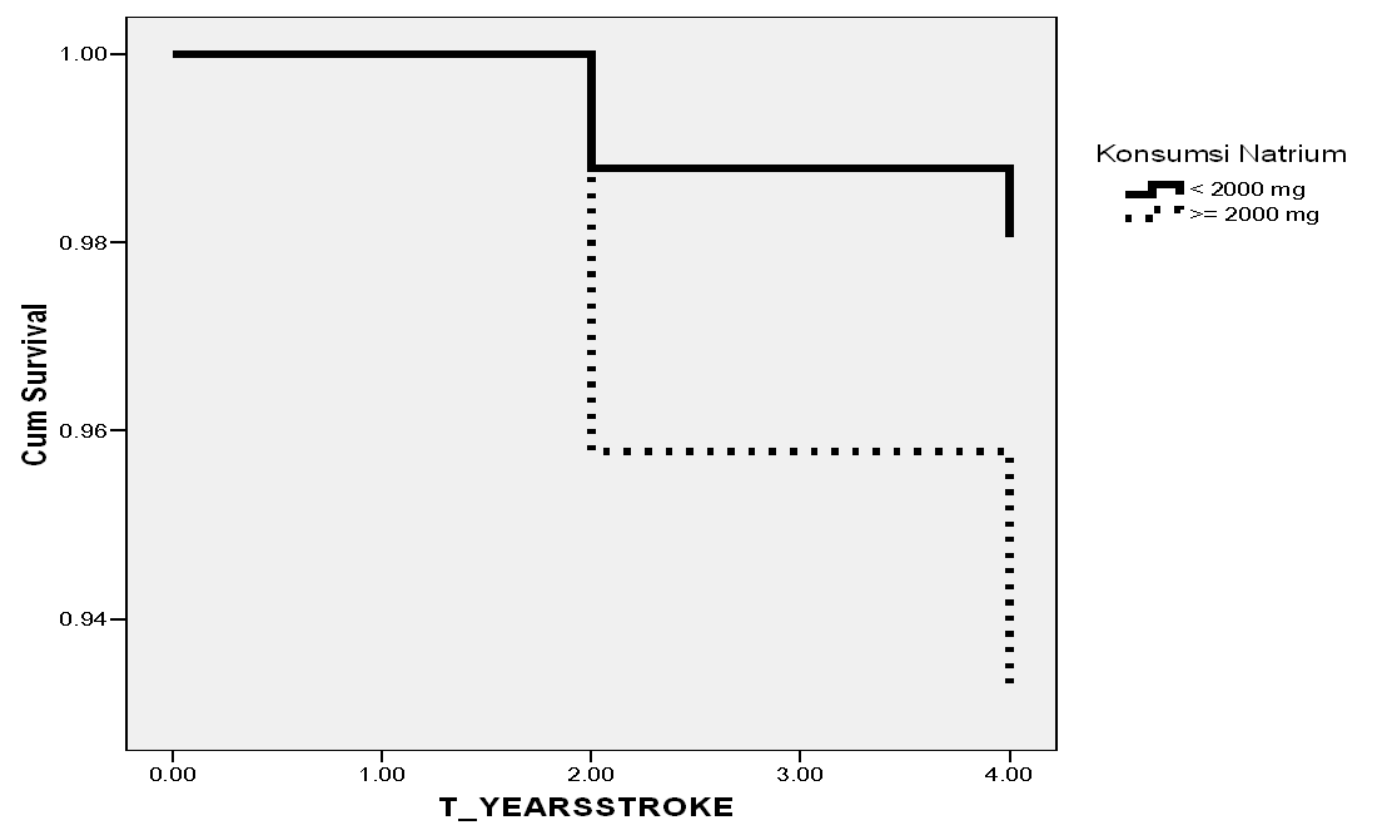

Gambar 2

Survival Hipertensi terhadap Stroke menurut Konsumsi Natrium dikontrol dengan Hiperglikemi, Tekanan Darah, Hiperkolesterol, Umur dan Kelamin 
Konsumsi natrium rendah ditemukan mencegah terjadinya stroke sebesar 78 persen (Hazard Ratio 0,28; 95\% Cl 0,14-0,70). Faktor lain yang ikut berkonstribusi pada model ini ditemukan meningkatkan risiko kejadian stroke. Hiperglikemi meningkatkan risiko stroke hampir 2 kali lipat (Hazard Ratio 1,93; 95\% Cl 1,09 3,78), hiperkolesterol meningkatkan risiko stroke 4 kali lipat (Hazard Ratio 4,04; 95\% Cl $2,05-7,96)$, tekanan darah yang tetap tinggi ditemukan meningkatkan risiko stroke 3,3 kali (Hazard Ratio 3,31; 95\% Cl 1,59-6,88), dan laki-laki ditemukan meningkatkan risiko stroke 2,5 kali (Hazard Ratio 2,57; 95\% Cl 1,32 $5,01)$. Sementara umur 40 tahun lebih juga ditemukan meningkatkan risiko namun tidak bermakna (Hazard Ratio 5,09; 95\% 0,69 17,32).

Tabel 2 memperlihatkan perbedaan waktu ketahanan (2 tahun-Survival Rate dan 4 tahunSurvival Rate) penyandang hipertensi terhadap kejadian stroke menurut kebiasaan mengonsumsi natrium (rendah vs tinggi), sesuai strata faktor-faktor yang ditemukan ikut berisiko terhadap kejadian stroke. Penyandang hipertensi yang biasa mengonsumsi natrium rendah, baik dalam waktu 2 tahun-pengamatan (97\% vs $90 \%$ ) maupun 4 tahun-pengamatan ( $94 \%$ vs $74 \%$ ) ditemukan mempunyai waktu ketahanan terhadap kejadian stroke lebih tinggi dibandingkan yang mengonsumsi natrium tinggi. Perbedaan waktu ketahanan tersebut dapat dilihat dengan lebih jelas pada Gambar 1.

Perbedaan waktu ketahanan penyandang hipertensi terhadap kejadian stroke menurut konsumsi natrium juga ditemukan bermakna pada semua faktor risiko yang ikut berpengaruh, kecuali pada kelompok umur 25-39 tahun. Penyandang hipertensi yang biasa mengonsumsi natrium rendah selalu mempunyai waktu ketahanan terhadap kejadian stroke lebih tinggi. Pada hiperglikemi ditemukan perbedaan waktu ketahanan lebih besar (2 tahun-survival rate $94 \%$ vs $67 \%$ dan 4 tahunsurvival rate $86 \%$ vs $52 \%$ ). Demikian halnya pada hiperkolesterol (2 tahun-survival rate $91 \%$ vs $65 \%$ dan 4 tahun-survival rate $85 \%$ vs $26 \%$ ), pada tekanan darah yang tetap tinggi (2 tahunsurvival rate $92 \%$ vs $88 \%$ dan 4 tahun-survival rate $91 \%$ vs $66 \%$ ), pada kelompok umur 40 tahun lebih (2 tahun-survival rate $96 \%$ vs $88 \%$ dan 4 tahun-survival rate $94 \%$ vs $68 \%$ ), dan pada laki-laki (2 tahun-survival rate $95 \%$ vs $78 \%$ dan 4 tahun-survival rate $89 \%$ vs $59 \%$ ). Tingginya waktu ketahanan terhadap kejadian stroke pada penyandang hipertensi yang biasa mengonsumsi natrium rendah setelah disesuaikan dengan faktor risiko lain yang ikut berpengaruh, baik dalam waktu 2 tahunpengamatan (98,9\% vs $95,9 \%)$ maupun 4 tahun-pengamatan $\quad(97,9 \%$ vs $92,9 \%)$ ditemukan tetap lebih tinggi dibandingkan penyandang hipertensi yang mengonsumsi natrium tinggi dan berbeda bermakna. Perbedaan waktu ketahanan tersebut dapat dilihat dengan lebih jelas pada Gambar 2.

\section{BAHASAN}

Studi ini telah berhasil menunjukkan bukti lebih tingginya waktu ketahanan terhadap kejadian stroke, bagi penyandang hipertensi yang mengonsumsi natrium rendah dibandingkan yang mengonsumsi natrium tinggi. Setelah disesuaikan dengan pengaruh faktor risiko lainnya, konsumsi natrium < 2000 $\mathrm{mg}$ per hari pada penyandang hipertensi mempunyai 2 tahun-survival rate sebesar 3 persen lebih tinggi dan 4 tahun-survival rate sebesar 5 persen lebih tinggi. Konsumsi natrium $<2000 \mathrm{mg}$ per hari pada penyandang hipertensi telah mencegah sebesar 78 persen kejadian stroke (Adjusted Hazard Ratio 0,28). Hasil ini mengkonfirmasi pengaruh natrium pada patofisiologi terjadinya stroke. Konsumsi natrium berlebihan akan menyebabkan meningkatnya cairan tubuh, dan membuat volume darah yang masuk ke jantung menjadi lebih besar. Pada hipertensi sangat berisiko terhadap penyakit jantung karena beban kerja jantung menjadi lebih berat. Apabila pembuluh darah arteri tidak kuat, dapat menyebabkan pecahnya pembuluh darah dan menyebabkan stroke total atau iskemik. 13,20,21 Penduduk Indonesia yang mengonsumsi natrium tinggi $(\geq$ $2000 \mathrm{mg}$ per hari) cukup tinggi yaitu 52,7 persen. Hal ini bisa menjadi penyebab meningkatnya prevalensi hipertensi dan stroke di Indonesia.

Hasil studi ini mengklarifikasi beberapa studi di Indonesia, yang tidak menemukan risiko konsumsi natrium terhadap hipertensi. ${ }^{22,23}$ Studi tersebut dilakukan melalui studi kros-seksional di masyarakat dan studi kasus-kontrol pada pasien hipertensi di rumah sakit, dan pengukuran konsumsi natrium dilakukan 
dengan wawancara menggunakan FFQ. Desain suatu penelitian dan metode pengumpulan data yang digunakan memang dapat mempengaruhi hasil penelitian yang diperoleh. Tidak ditemukannya pengaruh natrium terhadap tekanan darah pada penelitian tersebut, mungkin disebabkan under-estimate data konsumsi natrium yang dikumpulkan dengan FFQ secara cross-sectional dengan tekanan darah. ${ }^{19,24}$ Hasil analisis berdasarkan data studi kohor prospektif pada orang dewasa menemukan bahwa konsumsi natrium tinggi lebih mempercepat terjadinya hipertensi, dengan beda Hazard Rate sebesar 49 per 1000 orang per tahun. ${ }^{25}$ Data konsumsi pada penelitian ini dikumpulkan dengan recall makanan satu kali 24 jam dan wawancara menggunakan FFQ. Sementara kejadian stroke dipantau secara kohor prospektif. Dengan demikian dapat diklarifikasi bahwa rendahnya konsumsi natrium pada masyarakat Indonesia mencegah kejadian hipertensi dan stroke di Indonesia. Sebaliknya tingginya konsumsi natrium meningkatkan kejadian hipertensi dan stroke.

Hasil studi ini mengkonfirmasi hasil penelitian The Norfolk Cohort of the European Prospective, yang mendapatkan pengaruh asupan natrium pada hipertensi terhadap kejadian stroke. Penelitian dengan median masa pengamatan 7,2 tahun tersebut $(0,5-11,1$ tahun), dilakukan terhadap 608 pasien hipertensi dengan rerata asupan natrium $208 \pm$ $79 \mathrm{mmol}$ per hari (setara dengan asupan garam $12,1 \pm 4,6 \mathrm{~g}$ per hari). Penelitian telah menemukan 80 kejadian stroke, dan mendapatkan bahwa setiap peningkatan 10 mmol asupan natrium dari median intake 189 mmol natrium per hari, telah meningkatkan risiko stroke hampir 3 kali lipat (HR 2,99; 95\% $\mathrm{Cl}, 1,75-5,13, \mathrm{p}<0,001)$. Waktu ketahanan pasien hipertensi terhadap stroke juga ditemukan berbeda bermakna (Log rank 17,44, $p<0,001) \cdot{ }^{26}$

Hasil analisis studi ini juga sejalan dengan penelitian yang dilakukan di negara Asia, yaitu penelitian prospektif selama 7 tahun di Jepang yang menunjukkan pengaruh konsumsi natrium terhadap kejadian stroke dan kematian akibat stroke. Penelitian tersebut menunjukkan tingginya kejadian stroke dan kematian akibat stroke di Jepang yang lebih tinggi dibandingkan dengan negara barat. Hubungan tersebut terlihat dengan tingginya ekskresi natrium dalam 24 jam urine orang Jepang yaitu 167-201 $\mathrm{mmol} /$ hari, sementara pada orang Amerika adalah 96-201 mmol per hari. Sesuai konfirmasi peneliti, hal ini mungkin disebabkan karena jenis makanan tradisional Jepang yang sering menggunakan saos kedelai, pasta kedelai dan asinan (salty pickles). Jenis makanan tersebut telah menyumbang 74 persen total konsumsi natrium. ${ }^{27}$

Studi ini juga mendukung beberapa studi yang mendapatkan pengaruh konsumsi natrium rendah terhadap penurunan kejadian hipertensi dan stroke..$^{29-33}$ Mendukung juga hasil meta analisis dan sistematik review pada berbagai studi yang dilakukan secara observasional (kohor prospektif dan retrospektif) dan eksperimental, yang menghasilkan bahwa pengurangan konsumsi natrium pada orang dewasa, secara bermakna mengurangi tekanan darah sistol sebesar $3,39 \mathrm{~mm} \mathrm{Hg}(95 \% \mathrm{Cl} 2,46$ $-4,31$ ) dan tekanan darah diastol sebesar 1,54 $\mathrm{mm} \mathrm{Hg}(95 \% \mathrm{Cl} 0,98-2,11)$.

Sementara konsumsi natrium $<2000 \mathrm{mg}$ per hari telah menurunkan tekanan darah sistol sebesar $3,47 \mathrm{~mm} \mathrm{Hg}(95 \% \mathrm{Cl} 0,76-6,18)$ dan tekanan darah diastol sebesar $1,81 \mathrm{~mm} \mathrm{Hg}$ $(95 \% \mathrm{Cl} 0,54-3,08)$. Analisis tersebut juga menyimpulkan bahwa pengurangan konsumsi natrium secara bermakna telah menurunkan tekanan darah sebesar 1 persen pada normotensi dan 3,5 persen pada hipertensi. Juga sesuai dengan hasil penelitian yang dilakukan secara kohor prospektif pada 110792 orang Amerika berusia 40-79 tahun, yang mendapatkan bahwa setiap kenaikan $100 \mathrm{mmol}$ asupan natrium meningkatkan risiko insiden stroke lebih tinggi yaitu sebesar 32 persen, dan setiap kenaikan 100-mmol asupan natrium meningkatkan kematian akibat stroke sebesar 83 persen. ${ }^{29-34}$

Penelitian ini mempunyai keterbatasan antara lain, pengukuran konsumsi natrium, lemak dan gula dilakukan melalui recall makanan satu kali 24 jam. Jenis makanan yang dikonsumsi responden sangat bervariasi, sementara belum semua jenis makanan yang dikonsumsi tercantum dalam DKBM dan TKPI. Apabila data dikumpulkan melalui recall makanan tiga kali 24 jam, atau berdasarkan kadar natrium melalui urine 24 jam, maka data konsumsi yang diperoleh dapat lebih akurat. 


\section{SIMPULAN DAN SARAN}

\section{Simpulan}

Studi ini telah berhasil menunjukkan bukti lebih tingginya waktu ketahanan penyandang hipertensi yang mengonsumsi natrium rendah terhadap kejadian stroke, dibandingkan yang mengonsumsi natrium tinggi, dengan perbedaan 2 tahun-survival rate 3 persen lebih tinggi dan 4 tahun-survival rate 5 persen tinggi. Konsumsi natrium $<2000 \mathrm{mg}$ per hari pada penyandang hipertensi ditemukan telah mencegah sebesar 78 persen kejadian stroke.

\section{Saran}

Mengingat pentingnya upaya pencegahan stroke di Indonesia dan bukti yang cukup, baik tentang pengaruh konsumsi natrium tertinggi terhadap kejadian stroke maupun keuntungan mengonsumsi natrium < $2000 \mathrm{mg}$ per hari, maka program intervensi untuk mereduksi konsumsi garam atau natrium di Indonesia perlu segera diprioritaskan. Untuk mendukung program intervensi tersebut, peraturan terkait pencantuman nilai gizi pada makanan olahan dan siap saji, perlu mendapatkan dukungan legalisasi yang kuat dan dapat segera diterapkan di Indonesia.

\section{UCAPAN TERIMA KASIH}

Ucapan terima kasih kami sampaikan kepada Badan Litbangkes, khususnya Tim Studi Kohor Penyakit Tidak Menular yang telah memberikan kesempatan untuk menganalisis data penelitian ini. Terima kasih juga kami ucapkan kepada Dr. Atmarita MPH yang telah memberikan masukan pada tulisan ini.

\section{RUJUKAN}

1. World Health Organization. Global status report on noncommunicable diseases. Geneva: WHO, 2014.

2. Feigin $\mathrm{VL}$, Lawes $\mathrm{CM}$, Bennett DA, BarkerCollo SL, Parag V. Worldwide stroke incidence and early case fatality reported in 56 population-based studies: a systematic review. Lancet Neurol. 2009;8(4):355-69. http://dx.doi.org/10.1016/S14744422(03)00266-7
3. Mukherjee D, Patil CG. Epidemiology and the global burden of stroke. World Neurosurg. 2011;76(6 Suppl):S85-90. http://dx.doi.org/10.1016/j.wneu.2011.07.02 3

4. Badan Penelitian dan Pengembangan Kesehatan, Kementerian Kesehatan RI. Riset kesehatan dasar (RISKESDAS) 2007: laporan nasional. Jakarta: Badan Penelitian dan Pengembangan Kesehatan, Kementerian Kesehatan RI, 2007.

5. Badan Penelitian dan Pengembangan Kesehatan, Kementerian Kesehatan RI. Riset kesehatan dasar (RISKESDAS) 2013: laporan nasional. Jakarta: Badan Penelitian dan Pengembangan Kesehatan, Kementerian Kesehatan RI, 2013.

6. Zhao D, Liu J, Wang W, Zeng Z, Cheng J, Liu J, et al. Epidemiological transition of stroke in China: Twenty-one-year observational study from the SinoMONICA-Beijing project. Stroke. 2008;39:1668-74. DOI :http://dx.doi.org/10.1161/STROKEAHA.10 7.502807

7. Ministry of Health Singapore. National Registry of Disease Office. Singapore Stroke Registry Report No. 4: Trends In Stroke In Singapore 2005 - 2013. Diakses dari https://www.nrdo.gov.sg/ docs/librariesprovider3/default-documentlibrary/stroke

8. Hanchaiphiboolkul S, Poungvarin $\mathrm{N}$, Nidhinandana S, Suwanwela NC, Puthkhao $P$, et al. Prevalence of stroke and stroke risk factors in Thailand: Thai Epidemiologic Stroke (TES) Study. J Med Assoc Thai. 2011 Apr;94(4):427-36. Diakses dari https://www.ncbi.nlm.nih.gov/pubmed/2159 1527

9. Ueshima $H$, Sekikawa A, Miura K, Turin TC, Takashima N, Kita $\mathrm{Y}$, et al. Cardiovascular disease and risk factors in Asia: a selected review. Circulation. 2008;118(25):2702-9.

10. O'Donnell MJ, Chin SL, Rangarajan S, Xavier D, Liu L, Zhang $\mathrm{H}$, et al. Global and regional effects of potentially modifiable risk factors associated with acute stroke in 32 countries (INTERSTROKE): a case-control study. Lancet 2016;388(10046): 761-7. 
DOI: http://dx.doi.org/

$10.1016 / S 0140-$ 6736(16)30506-2

11. Djafri D, Hasanah SR. Meta-analisis faktor risiko modifiable penyakit kardiovaskular (hipertensi, penyakit jantung koroner, dan stroke) di Asia Tenggara. Laporan Hasil Penelitian. Padang: Fakultas Kesehatan Masyarakat Universitas Andalas, 2014.

12. Mozaffarian D, Fahimi S, Singh GM, Micha $R$, Khatibzadeh S, Engell RE, et al. Global sodium consumption and death from cardiovascular causes. N Engl J Med. 2014:371:624-34.

13. Goldstein LB: Guidelines for the Primary Prevention of Stroke: A Guideline for Healthcare Profesionals from the American Heart Association I American Stroke. Association Stroke. 2010.

14. World Health Organization. Action Plan for the Prevention and Control of noncommunicable diseases in South-East Asia, 2013-2020. New Delhi: Regional Office for South-East Asia, 2013.

15. Gunn JP, Blair NA, Cogswell ME, Merritt RK, Labarthe DR, Curtis CJ, et al. CDC grand rounds: dietary sodium reduction time for choice. MMWR Morb Mortal Wkly Rep. 2012;61(05):89-91.

16. World Health Organization (WHO). Guideline: Sodium intake for adults and children. Geneva: World Health Organization. 2012.

17. Badan Penelitian dan Pengembangan Kesehatan, Kementerian Kesehatan RI. Survei Konsumsi Makanan Individu 2014: laporan nasional. Jakarta: Badan Penelitian dan Pengembangan Kesehatan, Kementerian Kesehatan RI, 2015.

18. Pusat Penelitian Upaya Kesehatan Masyarakat, Badan Penelitian dan Pengembangan Kesehatan. Laporan Studi Kohort Penyakit Tidak Menular 2015. Jakarta: Badan Penelitian dan Pengembangan Kesehatan, Kementerian Kesehatan RI, 2015.

19. Cobb LK, Anderson CA, Elliott $P$, Hu FB, Liu K, Neaton JD, et al. Methodological issues in cohort studies that relate sodium intake and cardiovascular disease outcomes: a science advisory from the American Heart Association. Circulation 2014; 129(10):1173-86.
20. Pokdi Stroke Perhimpunan Dokter Spesialis Saraf Indonesia (PERDOSSI). Guideline Stroke Tahun 2011. Jakarta: PERDOSSI, 2011.

21. Hocker S, Morales-Vidal S, Schneck MJ. Management of Arterial Blood Pressure in Acute Ischemic and Hemorrhagic Stroke. In Biller J, Evans RW. Neurologic Clinics. Advances in Neurologic Therapy. WB Saunders Company, Philadelpia, 2010, pp $863-886$.

22. Alfiana $\mathrm{N}$, Bintanah $\mathrm{S}$, Kusuma HS. Hubungan asupan kalsium dan natrium terhadap tekanan darah sistolik pada penderita hipertensi rawat inap di RS Tugurejo Semarang. Jurnal Gizi Universitas Muhammadiyah Semarang. 2014;3(1) [sitasi tanggal 13 Agustus 2016). Diakses dari:

http://www.jurnal.unimus.ac.id/index.php/jgi zi/article/download/1322/1377

23. Jannah M, Sulastri D, Lestari Y. Perbedaan asupan natrium dan kalium pada penderita hipertensi dan normotensi masyarakat etnik Minangkabau di Kota Padang. Jurnal Kesehatan Andalas. 2013; 2(3) [sitasi 25 Juli 2016]. Diakses dari: http://www.jurnal.fk.unand.ac.id lindex.php/jka/article/view/.

24. O'Donnell MJ, Mente A, Smyth A, Yusuf S. Salt intake and cardiovascular disease: why are the data inconsistent? Eur Heart J. 2013;34:1034-40.

25. Rahajeng E, Kristanti D, Kusumawardani N. Perbedaan laju kecepatan terjadinya hipertensi menurut konsumsi natrium. Penel Gizi Makan. 2016;39(1): 45-53

26. Polonia J, Monteiro J, Almeida J, Silva $J A$, Bertoquini S. High salt intake is associated with a higher risk of cardiovascular events: a 7.2-year evaluation of a cohort of hypertensive patients. Blood Press Monit. 2016 Oct;21(5):301-6. Diakses dari www.ncbi.nlm.nih.gov/pubmed/27495189. doi: 10.1097/MBP.0000000000000205.

27. Sakata K, Hozawa A, Nakamura $Y$, Nishi N, Kasagi $F$, et al. Dietary sodium-topotassium ratio as a risk factor for stroke, cardiovascular disease and all-cause mortality in Japan: the NIPPON DATA80 cohort study. Published online 2016 Jul 13. doi: 10.1136/bmjopen-2016-011632 
28. Li N, Yan LL, Niu W, Labarthe D, Feng X, Shi J, et al. A large-scale cluster randomized trial to determine the effects of community-based dietary sodium reduction-the China Rural Health Initiative Sodium Reduction Study. Am Heart J. 2013;166(5):815-22.

29. Kotchen TA, Cowley Jr AW, Frohlich ED. Salt in health and disease-a delicate balance. N Engl J Med. 2013;368:122937.

30. Aburto NJ, Ziolkovska A, Hooper L, Elliott P, Cappuccio FP, Meerpohl JJ. Effect of lower sodium intake on health: systematic review and meta-analyses. BMJ. 2013;346:f1326.

31. Stolarz-Skrzypek K, Kuznetsova T, Thijs L, Tikhonoff V, Seidlerova J, Richart T, et al. Fatal and nonfatal outcomes, incidence of hypertension, and blood pressure changes in relation to urinary sodium excretion. JAMA. 2011;305:1777-85.

32. Graudal NA, Hubeck-Graudal T, Jurgens $G$. Effects of low sodium diet versus high sodium diet on blood pressure, renin, aldosterone, catecholamines, cholesterol, and triglyceride. Cochrane Database Syst Rev. 2011;11:CD004022.

33. Campbell N, Correa-Rotter R, Neal B, Cappuccio FP. New evidence relating to the health impact of reducing salt intake. Nutr Metab Cardiovasc Dis. 2011;21:6179.

34. Whelton PK, Appel LJ. Sodium and Cardiovascular Disease: What the Data Show. Am J Hypertens. 2014 Sep;27(9):1143-5. doi: 10.1093/ajh/hpu138. 